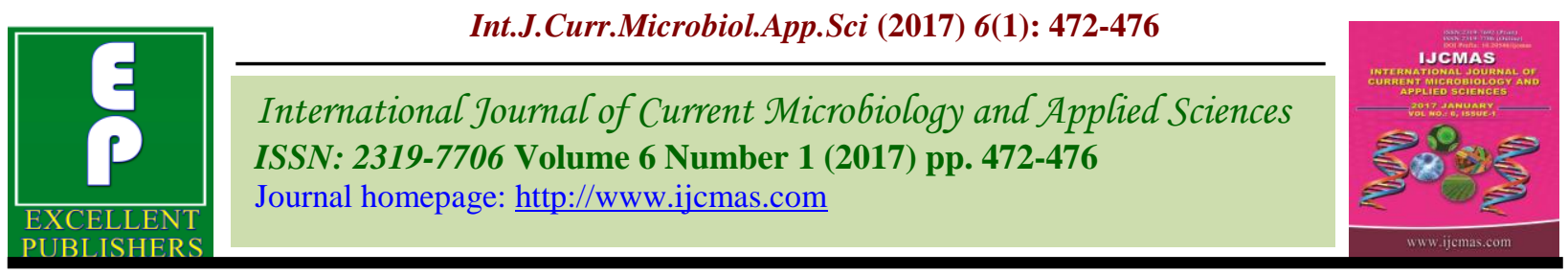

Original Research Article

http://dx.doi.org/10.20546/ijcmas.2017.601.055

\title{
First Report of Ruddy-breasted Crake Porzana fusca (Linnaeus, 1766) from Chhattisgarh, India
}

\begin{abstract}
Sushil Kumar Dutta*
Department of Zoology, Government PG College, Jagdalpur, Bastar, Chhattisgarh, 494001, India

*Corresponding author

A B S T R A C T

Keywords

Ruddy-breasted

Crake, Dalpat Sagar

Lake, Bastar

Plateau, fledglings

Chhattisgarh, India.

Article Info

Accepted:

23 December 2016

Available Online:

10 January 2017

More than 50 species of wetland dependent birds have been observed roosting and breeding in the lake (pers. obsv.). Some of the submerged and emergent hydrophytes along the littoral and little above the littoral zone in the lake are Hydrilla verticillata, Potamogeton sp., Nelumbo nucifera, Lotus stellata, Typha angustifolia and Oryza rufipogon. On 2 January 2015, a juvenile and three adult individuals of Ruddy-breasted Crake Porzana fusca were sighted in the marsh and swampy area to the littoral zone of the Dalpat Sagar Lake upon entry from its South-eastern direction. The sighting frequency of this species along with young chicks was noted to be high in the month of May and June (summer). Frequent sightings were recorded near to Pujari Munda paddy field opposite to the bund of Dalpat Sagar Lake in the north.
\end{abstract}

\section{Introduction}

Ruddy-breasted Crake Porzana fusca being a widespread resident and has sporadic distribution in Peninsular India (Grimmett et al., 2011). However, the species was unreported from central India (Chandra \& Singh, 2004, Chandra et al., 2015). This note describes the occurrence and first reporting of the species from Chhattishgarh at Dalpat Sagar Lake in Jagdalpur $\left(19^{\circ} 05^{\prime} 55.5^{\prime \prime} \mathrm{N}\right.$, 82 00'46.0"' E; WGS-84), Bastar district. Dalpat Sagar, spread over an area of 142.45 ha. is a dammed lake located in Jagdalpur town. More than 50 species of wetland dependent birds have been observed roosting and breeding in the lake (pers. obsv.). Some of the submerged and emergent hydrophytes along the littoral and little above the littoral zone in the lake are Hydrilla verticillata, Potamogeton sp., Nelumbo nucifera, Lotus stellata, Typha angustifolia and Oryza rufipogon. Eichhornia crassipes, Ipomoea carnea var. fistulosa, Alternanthera philoxeroides and Indigifera pulchella. There are two islands at the middle of the water body, approachable only by a boat. A large portion of these land areas get submerged 
during monsoon and expose in late winter and throughout summer. The land mass supports growth of trees like Ficus bengalensis, F. religiosa, $F$. glomerata, Mangifera indica and Lannea grandis (Figure-1).

On 2 January 2015, a juvenile and three adult individuals of Ruddy-breasted Crake Porzana fusca were sighted in the marsh and swampy area to the littoral zone of the Dalpat Sagar Lake upon entry from its South-eastern direction. In this area three to four sewagewater channels conjoin the wetland. This species can be distinguished from other crake species by combination of dull chestnut under-parts, unmarked dark olive-brown upperparts, indistinct dark brown and white barring on rear flanks and undertail-coverts (much more restricted than in Slaty-legged and Andaman crakes) and red legs. Juveniles are dark-olive brown with white-barred under-tail coverts and fine greyish-white mottling / barring on rest of under parts. Legs are duller and iris is brown in colour (rather than red in adult) (Grimmett et al., 2011).

The appearance of adult bird at the Dalpat Sagar Lake was olive-brown in the upper part with distinct reddish under part along with red iris and red legged (Figure-3A\&B). But the juvenile bird's upper part was dark olivebrown with tinges of white bars in the underbelly. Its iris is dark brown and legs are dull red (Figure-2). This species was frequently seen and heard in this area, any time of the day. It was noted that the juveniles were more cryptic or secretive than the adults as they rarely come out to open areas (bunds). Often adults also immediately take shelter into the thickets of the Ipomoea carnea var. fistulosa, Eichhornia crassipes and Alternanthera philoxeroides underbrush at the slightest disturbance.

The sighting frequency of this species along with young chicks was noted to be high in the month of May and June (summer). Frequent sightings were recorded near to Pujari Munda paddy field opposite to the bund of Dalpat Sagar Lake in the north (Figure-4A\&B). The species was recorded consistently throughout the year. The above observations with fledglings and young chicks; plausibly suggests that the species is using this wetland as its breeding habitat and reasonably as local residence in the Central India.

Fig.1 Dalpat Sagar Lake

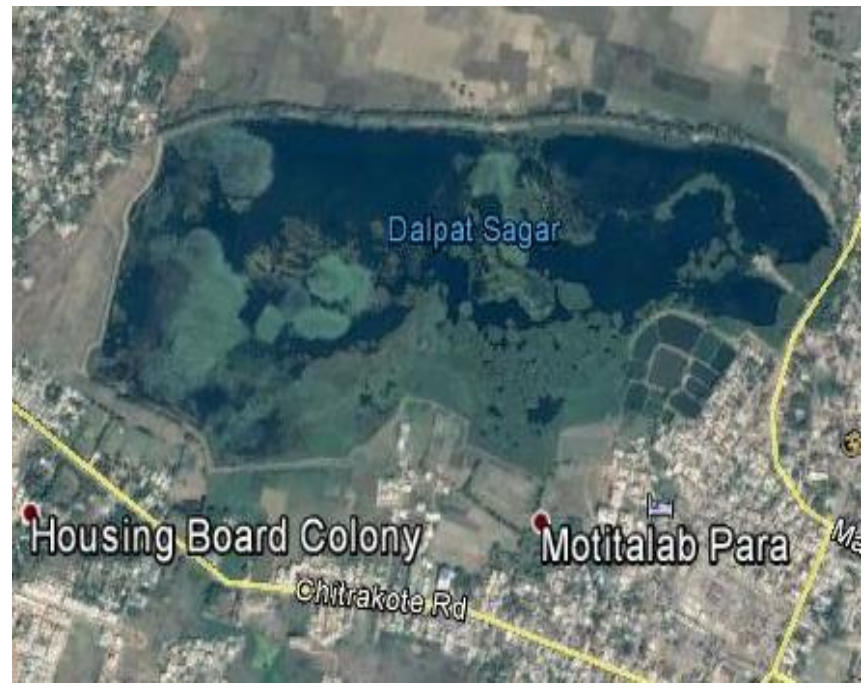


Fig.2 Juvenile Ruddy-breasted Crake Porzana fusca

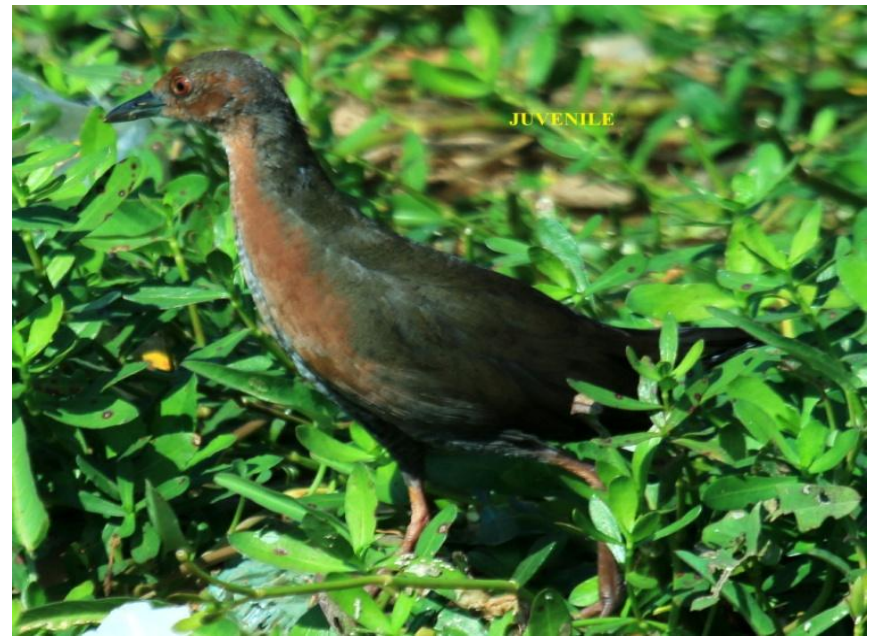

Fig.3 Adult Ruddy-breasted Crake Porzana fusca

A

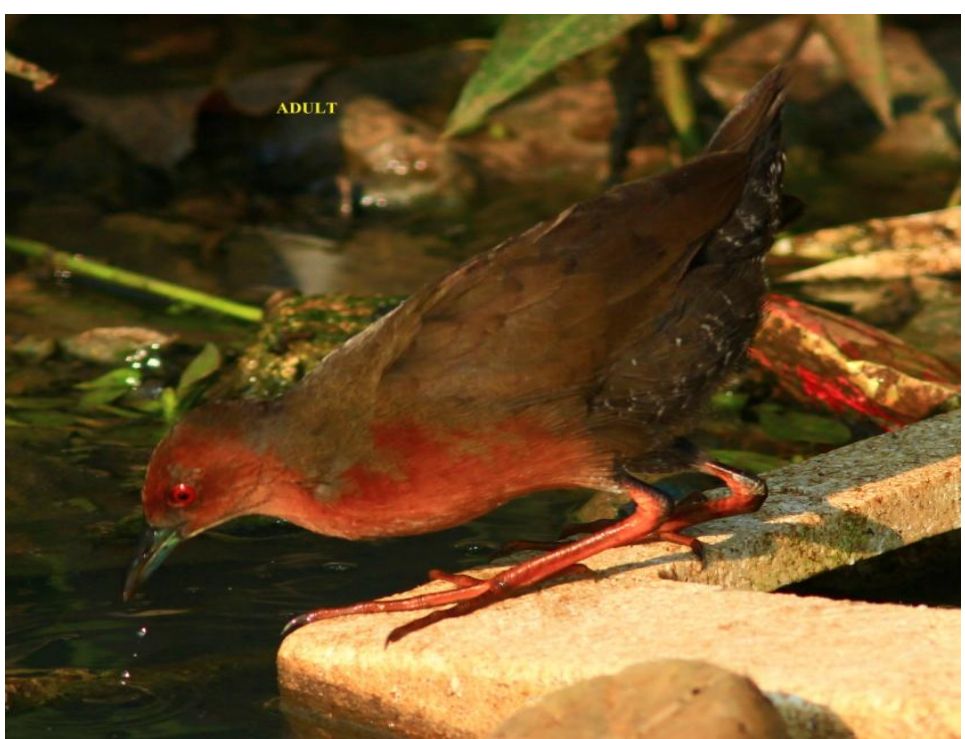

B

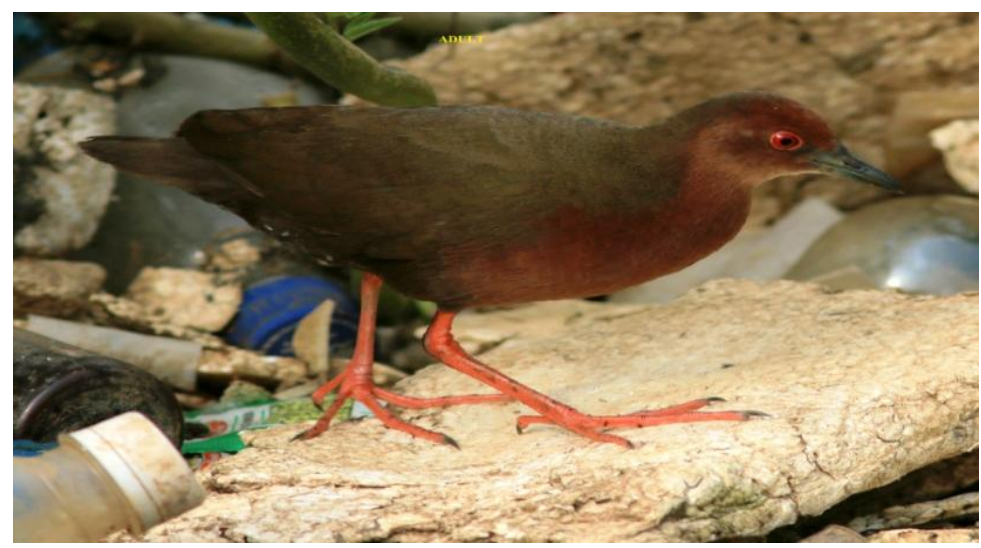


Fig.4 Ruddy-breasted Crake with fledglings

A

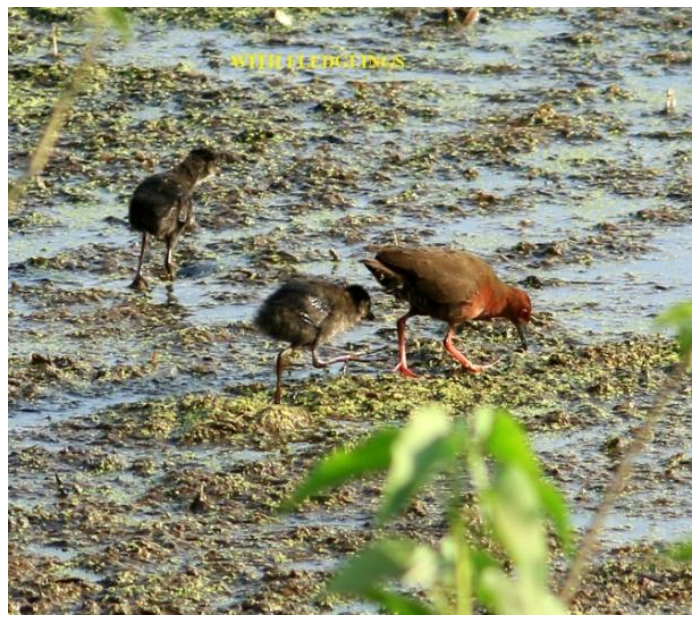

B

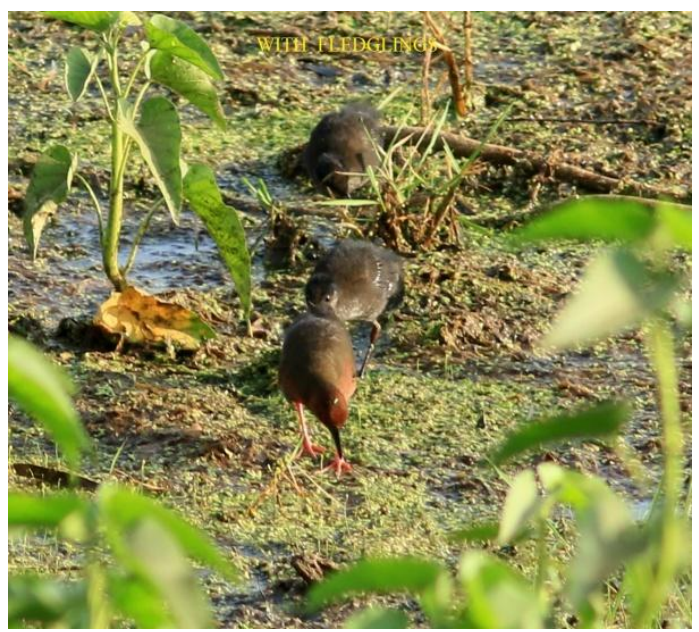

This species has been reported from Chilika lagoon, Odisha (Dev, 2013) (C.f.360 km from the present sighting locality). It may also be taken on a record that this species has been sighted from the month of April to June 2016 in the Janjgir district of the Chhattisgarh (Kumar Singh, pers. Comm, 2016) which is the closest distribution record and c.f. $328 \mathrm{~km}$ from the present locality. The present habitat preference of the species in the Dalpat Sagar Lake suggests that it may be a common species in other wetlands of Central India with similar ecotype and has possibly remained unnoticed due of its small size, cryptic, secretive and wary nature. Similarly, the present author has also reported several new record of avifauna from the Bastar Plateau of Chhattisgarh which needs further studies in the adjacent areas of Central India (Dutta 2015, 2016a, 2016b). Bastar district is largely inhabited by several tribal communities: have been hunting birds on regular basis and it was learnt that this bird was in the target-species for poaching in the past along with other wetland birds. However, the active surveillance of Forest Department and conservation pressure by the local media; it seems the avifauna of Dalpat sagar is now well preserved and some species are possible reviving in diversity and numbers. 


\section{Acknowledgements}

I am thankful to Dr. P. Mohapatra, Dr. M. L. Naik, Dr. Muntaz Khan, Prof. V. C. Awasthi and Dr. P.R.S. Nagi for helping in identification of bird and plant species, preparation of the manuscript and for thorough help.

\section{References}

Chandra, K. \&, Singh, R.K. 2004. Avifauna of Madhya Pradesh and Chhattisgarh. Zoos' Print J., 19 (7): 1534-1539.

Chandra, K., Dutta S.K., Gupta R.P., \& Raha, A. 2015. Diversity and conservational status of avifauna in Bastar plateau of Chhattisgarh, India. Ambient Sci., 02(1): 31-43.
Dev, U.N. 2013. A field guide to the birds of Chilika, Odisha Forestry Sector Development Project, Bhubaneswar, Odisha, 1-281 pp.

Dutta, S.K. 2015. First report of Rufousbellied Eagle, Hieraaetus kienerii (E. Geoffroy, 1835 from Chhattisgarh, India. Biolife, 3(2), pp 561-563.

Dutta, S.K. 2016a. Sighting of Spot-billed Pelican Pelecanus philippensis in Bastar Plateau, Chhattisgarh, India. Indian Birds, 11(4): 100.

Dutta, S.K. 2016b. First report of Amur Falcon, Falco amurensis Radde, 1863 from Chhattisgarh, India. Biolife, 4(3): pp 437-440.

Grimmett, R., Inskipp, C.\& Inskipp, T. 2011. Birds of the Indian Subcontinent, Christopher Helm, London, 1-528 pp.

\section{How to cite this article:}

Sushil Kumar Dutta. 2017. First Report of Ruddy-breasted Crake Porzana fusca (Linnaeus, 1766) from Chhattisgarh. Int.J.Curr.Microbiol.App.Sci. 6(1): 472-476.

doi: http://dx.doi.org/10.20546/ijcmas.2017.601.055 